current required in the ring is Ioo million amperes. The magnetic field due to this current at the earth's surface is given as $68 \mathrm{I} \gamma$, which represents a magnetic storm of the first order.

In considering how the question is affected by the presence of the earth's atmosphere, Störmer inclines to the views of Wegener (while not committing himself to the existence of a gas, "geocoronium," of one-fifth the density of hydrogen). At altitudes above roo kilometres there is supposed to be no trace of anything but the lighter gases, especially hydrogen (and geocoronium, if it exists). In agreement with Lenard, Störmer concludes that ordinary kathode rays coming from space would be absorbed in the upper hydrogen atmosphere before reaching the roo kilometres level, that $\beta$-rays of radium would be absorbed in the nitrogen atmosphere at heights of 50 to 70 kilometres-a common altitude for the lower border of auroral "curtains"-and that the rays forming the lowest aurora he has measured must have a greater penetration than $\beta$-rays. Fairly substantial evidence has been advanced by Paulsen and others that auroras in the auroral belt, especially in Greenland, sometimes come much below the lowest height, $3^{6}$ kilometres, observed by Störmer at Bossekop. This tends to support Birkeland's latest views as to an enormously high velocity in the rays if they originate in the sun. On the other hand, there seems reason to accept Störmer's view that auroras seen in low latitudes are usually at considerably greater heights than those seen in the Arctic. Thus aurora in low latitudes would seem to arise from rays of less, not of higher, penetration than those in high latitudes, which seems inconsistent with Birkeland's hypothesis.

Störmer's mathematical work, like Birkeland's, assumes the motion of the individual corpuscle to be unaffected by the presence of other corpuscles. This is one of the principal criticisms urged by Prof. Schuster, ${ }^{2}$ who concluded that the scattering inevitably produced is fatal to Birkeland's theory, so far at least as magnetic storms are concerned. The same criticism would seem to apply, with at least equal force, to Störmer's theory. It would thus be of great interest to have Prof. Störmer's views on the validity of Prof. Schuster's criticisms. Meantime, considering the calibre of the protagonists, the prudent course seems to be to "wait and see." But whatever the fate of Störmer's theoretical work may be, his photographs of aurora clearly constitute a fundamental advance towards exact knowledge. In temperate and southern Europe, aurora and large magnetic storms are both rare events, and their coincidence of occurrence seems the rule rather than the exception. A total absence of physical connection between the two phenomena seems thus almost inconceivable. The careful intercomparison of measurements of aurora-rendered possible by Störmer's work-with contemporaneous records from magnetic observatories is clearly one of the most promising methods of getting at the root of the matter.

C. Chree.

2 Roy. Soc. Proc., A. 85, rgxr, p. 44.

\section{PROF. THOMAS WINTER.}

PROF. THOMAS WINTER, of the University College of North Wales, Bangor, whose death we recorded in our last issue, was the son of Mr. Thomas Winter, of Lotherton Park, Aberford, Leeds. Born in 1866 , he was educated at the Darlington Grammar School under Dr. Wood, and afterwards proceeded to the University of Edinburgh, where in I 888 he graduated in arts with honours in natural science. On leaving the University he became a master at a Scarborough school, and later at the Norfolk County School at Dereham. The son of a successful practical farmer, and equipped with a university training in natural science, he was naturally attracted to the development of schools of agriculture in the provincial colleges and universities which marked the later decades of the last century. In $x 89 \mathrm{I}$ he was appointed assistant lecturer in agriculture at the University College of North Wales, Bangor. In I892 he accepted a similar appointment at the Yorkshire College, Leeds, as it then was, but returned in 1894 to Bangor as head of the department of agriculture, a post which he occupied for the next eighteen years. It is thus in North Wales that his life-work chiefly lay, and where the stimulus which he gave to the cause of agricultural education will be longest felt.

The work of a school of agriculture has its internal and external sides. On the internal side courses of instruction have to be provided with a view to certificates, diplomas, and degrees. On the external side the agricultural community within the area served by the school has to be considered, and extension lectures, field experiments, and instruction in dairy-work have to be provided for the benefit of those who cannot reach the college. In both these aspects of the work of his chair, Prof. Winter achieved a rare success. Within the University of Wales his sound judgment contributed to the framing of the existing scheme of instruction for the degree in agriculture and rural economy, the marked feature of which is the requisition of an adequate acquaintance with the pure sciences, prior to the study of their applications to agriculture. It was also to Prof. Winter's fostering care that the chair of forestry was established at Bangor.

In the external work of the department his gift of organisation and his tact and good sense have greatly contributed to the removal of the distrust of agricultural education among old-fashioned farmers. Not the least contribution to this end was his successful management of a college farm, where experiments in cropping and brceding have been carried out, and where the visits of farmers and their sons and daughters have always been welcomed. Prof. Winter's death while still in the prime of life will be greatly deplored by his colleagues on the senates of his college and university, by his former pupils scattered in many parts of the world, and not least among the farmers of the North Welsh counties. 